\title{
The Effect of Hydrogen Cyanamide on Bud Break and Yield of Kiwifruit in Northwest Portugal
}

A. Veloso and M. Oliveira

DRAEDM-Divisão de Vitivinicultura e

Ffruticultura, Quinta de Sergude, Sendim, 4610-764 Felgueiras, Portugal

\author{
M.D.C. Antunes* \\ Universidade do Algarve, F.E.R.N., \\ Campus de Gambelas \\ 8000-117 FARO, Portugal
}

Keywords: Actinidia deliciosa, Dormex ${ }^{\circledR}$, bud fertility, marketable fruit

\begin{abstract}
Kiwifruit (Actinidia deliciosa cv. Hayward) was introduced into Northwest Portugal at the early 1970's increasing its importance up to date. The main objective of orchard management is to find out the cultural techniques suitable for the region, in order to obtain good yield and quality fruit. Winter chilling $\left(\leq 7.2^{\circ} \mathrm{C}\right)$ plays a significant role in kiwifruit break dormancy. Insufficient chilling can be countered by chemical agents as hydrogen cyanamid (Dormex). The objective of this research was to quantify the efficiency of hydrogen cyanamide $(0 \%, 4 \%$, and $6 \%$ ) on bud break dormancy and yield and fruit quality. Experiments were carried out over two years on a mature 'Hayward' kiwifruit orchard. The results showed that $4 \%$ Dormex was the most efficient in increasing marketable yield due to increase of flower bud formation and higher level of fruit set. There were no significant differences among treatments in soluble solids content, flesh firmness and dry weight. Titrable acidity showed higher values with increased Dormex concentration.
\end{abstract}

\section{INTRODUCTION}

The introduction of Actinidia deliciosa in Portugal represents a case of success in fruit production. In only two decades it become the fruit crop economically more important in the region of Entre Douro e Minho (North Portugal) with $74 \%$ of the national kiwifruit cultivated area (SIMA, 1999). However, concurring in a high competitive market, kiwifruit from this region showed to be of inferior quantity and quality. The low knowledge of the physiology of this crop and of the technology of orchard pruning and conduction, were, between others, limiting factors for orchard profitability.

Actinidia deliciosa as other deciduous fruit trees from temperate climate is susceptible to the excess or lack of cold in the winter. This last situation is one of the main factors limiting orchard profitability in the littoral of Entre Douro e Minho region. Many authors refer the importance of a number of 600-800 hours of chilling temperatures $\left(<7.2^{\circ} \mathrm{C}\right)$ for the plants to have good bud break and fruit set and consequently a good yield (Grant et al., 1994; Salinero and Lema, 1999). In order to overcome the problem of lack of chilling hours there exists in the market several products containing growth regulators, like hydrogen cianamyde, that have been tested in different crops as vine (Pires et al., 1999) and kiwifruit (Costa et al., 1997; Powel, 1997). This compound has an identical effect with the chilling temperatures in the reduction of the enzyme catalase in vegetal tissues, with the increase of the pentose phosphate, inducing dormancy break in cryophilic plants (Silveira et al., 1999). In this way, hydrogen cyanamyde contributes to a considerable increase in fruit yield.

The aim of this research was to study the effect of the application of different concentrations of Dormex (hydrogen cyanamyde) on Actinidia deliciosa cv. Hayward, on the increase of fruit yield and quality, in the region of Entre Douro e Minho in Portugal.

\footnotetext{
* Corresponding author. Tel.: +351 289800930; Fax: +351 289818419; e-mail: mantunes@ualg.pt
} 


\section{MATERIAL AND METHODS}

The experiment was set in an orchard located in Northwest Portugal about $2 \mathrm{Km}$ from the littoral, during two seasons, in 1997/98 and 1998/99. Treatments were made in only one application of Dormex (aqueous solution containing $520 \mathrm{~g} / \mathrm{L}$ of hydrogen cianamyde) in all plant, uniformly by a manual pulverizer. It was used 1 litre of solution per plant. Treatments consisted of Dormex application in concentrations of 0 (control), 4 and $6 \%$ in water. Dormex was applied after winter pruning when the buds presented the phenological stage A1 and during the morning. Each treatment was repeated 3 times in 3 plants per replication. Pruning was homogenized to eliminate differences between treatments. Were registered the number of buds left after pruning, the number of breaking buds, the number of fertile buds and the number of flowers. From these data were done the following indexes: bud break index $(\mathrm{AI})=$ (number of breaking buds / number of buds left after pruning $* 100$; fertility index $(\mathrm{FI})=$ number of flowers $/$ number of fertile buds; real fertility $(\mathrm{RF})=$ number of flowers / number of buds left after pruning (Testolin and Messina, 1985; Corral et al., 1987).

Kiwifruit were harvested and calibrated per plant in a calibrator set for these fruits. The soluble solids content $\left({ }^{\circ} \mathrm{Brix}\right)$ was measured with a hand Atago refractometer with automatic temperature correction. Firmness was recorded by puncture, after skin removal, with a hand penetrometer fitted with a flat $8 \mathrm{~mm}$ tip. Titrable acidity was measured by neutralising $10 \mathrm{ml}$ fruit juice with a solution of $0.1 \mathrm{~N}$ of $\mathrm{NaOH}$. One $\mathrm{ml}$ of $0.1 \mathrm{~N} \mathrm{NaOH}$ solution is converted in citric acid multiplying by a coefficient of 0.64 (Alavoine et al., 1998 cited by Blanchet, 1997). The dry matter was calculated by drying the fruits in a woven at $65^{\circ} \mathrm{C}$ till to reach a constant weight.

\section{RESULTS}

The results showed an anticipation of the bud break date in the plants treated with Dormex in comparison with control (Table 1). In table 2 it can be seen significant differences between fruit treated with Dormex and control for bud break indexes, fertility and real fertility, marketable yield and titrable acidity of kiwifruit. The mean distribution of fruits per category in the different treatments is presented in Fig. 1. Here it can be seen that for almost all categories the yield of plants treated with Dormex was superior to that of control plants.

\section{DISCUSSION}

\section{Bud Break Date}

Dormex was applied 35-45 days before the predicted bud break date, which in the region occurs normally in the second decade of March. Our results showed that Dormex anticipated this date by approximately a week and, simultaneously, did not cause any change in the date of full bloom and maturation of the fruits.

\section{Bud Break and Bud Fertility}

In the number of breaking buds, which represent the sum of vegetative buds and fertile buds, there were observed significant differences between control and Dormex treated plants without significant differences between Dormex treatments. If we look only at the vegetative buds, we observe that there were no significant differences among treatments presenting the control even a slightly higher number of vegetative buds. However, in the number of fertile buds and total number of flowers it is observed highly significant differences, presenting the plants treated with Dormex a bigger number of flowers in comparison with the control. The bud break index did not show significant differences among treatments, even though plants treated with Dormex showed slightly higher values. The fertility index (FI) and the real fertility (RF) presented significantly higher values in Dormex treatments than in control. The real fertility presented highly significant differences between Dormex and control treatments. This index is the most important parameter when it is pretended to evaluate the effect of Dormex on the 
optimisation of the production because it represents the potential production in relation to the number of buds left after pruning. Although there were little differences between Dormex treatments they were not significant.

\section{Fruit Production}

The different quality parameters of the kiwifruits analysed as dry fruit weight, soluble solids content and firmness, did not show significant differences among treatments. The exception was the titrable acidity that showed higher values with increased concentration of Dormex applied.

\section{ACKNOWLEDGMENTS}

Acknowledgements are due to José Maia for disposability of his orchard and other facilities, to the technicians Óscar Pereira and Alcino Castro for their collaboration in fruit analyses and counting and to the Cooperativa Agrícola de Felgueiras for fruit calibration.

\section{Literature Cited}

Alavoine, F., Crochon, M. Fady, C. Fallot, J. Moras, P. and Pech J-C. 1988. Taste quality in fruit. CEMAGREF. Aix en Provence.

Blanchet, P. 1997. Maturity and post-harvest behavior of na early maturing kiwifruit selection. In Proc. Third Int. Symp. On kiwifruit. Eds. E. Sfakiotakis, J. Porlingis. Acta Hort. 444. Vol.2. ISHS. 507-512.

Corral, C. S.; Casal, O. A.; Fernández, P. V. 1997. Ciclo vegetativo de Actinidia deliciosa en la comunidad gallega. Actas de Horticultura. Vol. 15. 521-528.

Costa, G; Vizzotto, G.; Lain, O. 1997. Fruiting performance of kiwifruit cv. Hayward affected by use of cyanamide. Proc. Third Int. Symp. on kiwifruit. Eds. E. Sfakiotakis, J. Portingis. Acta Hort. 444. Vol.2. ISHS. 473-478.

Pires, E. J. P.; Pommer, C. V.; Terra, M. M. e Passsos, I.R. S. 1999. Effets de la cyanamide de calcium et de la cyanamide hydrogène sur la levée de dormance des bourgeons, le débourrement et le rendement du cépage niagara rosé dans la region de Jundiaí, Ėtat de São Paulo, Brésil. Bulletin O.I.V. Vol.72. 457-483.

Powell, A. A. 1997. The effects of Dormex on replacing lack of chilling in kiwifruit. Horticulturist-Fruits. www.acesag.auburn.edu/departement/peaches/kiwidormex.html.

Salinero, M. C.; Lema, M. J. 1999. Efectos de la cianamida de hidrogeno en la brotacion, fertilidad, composicion y produciones de kiwi (Actinidia deliciosa, Chevalier, Liang \& Ferguson). Prod. Prot. Veg. Vol. 14 (3). 355-366.

Silveira, H. L.; Gomes, R.; Aguiar, L. 1999. Guia dos produtos fitofarmacêuticos,. condições de utilização, reguladores de crescimento. DGPC. Oeiras.

SIMA. 1999. Anuário Hortofrutícola. MADRP. Lisboa.

Testolin, R.; Messina, R.; Youssef, J. 1985. Indagine sulla fertilità dell'actinidia. Rivista de Frutticoltura. No 5. 59-64. 


\section{$\underline{\text { Tables }}$}

Table 1. Dates of hydrogen cyanamyde application and of the observation of the different phenological stages.

\begin{tabular}{lllllll}
\hline Ano & $\begin{array}{l}\text { Treat- } \\
\text { ment }\end{array}$ & $\begin{array}{l}\text { Application } \\
\text { date }\end{array}$ & $\begin{array}{l}\text { Bud } \\
\text { break }\end{array}$ & $\begin{array}{l}\mathrm{N}^{\text {o }} \text { of days } \\
\text { between appli- Full } \\
\text { cation and } \\
\text { bud break }\end{array}$ & $\begin{array}{l}\text { Furvest } \\
\text { bloom }\end{array}$ & Harver \\
\hline $1997 / 98$ & $0 \%$ & 98.02 .09 & 98.03 .20 & - & 98.05 .22 & 98.11 .12 \\
& $4 \%$ & 98.02 .09 & 98.03 .12 & 31 & 98.05 .22 & 98.11 .12 \\
& $6 \%$ & 98.02 .09 & 98.03 .12 & 31 & 98.05 .22 & 98.11 .12 \\
$1998 / 99$ & $0 \%$ & 99.02 .19 & 99.03 .25 & - & 99.05 .25 & 99.11 .09 \\
& $4 \%$ & 99.02 .19 & 99.03 .18 & 27 & 99.05 .25 & 99.11 .09 \\
& $6 \%$ & 99.02 .19 & 99.03 .18 & 27 & 99.05 .25 & 99.11 .09 \\
\hline
\end{tabular}

Table 2. Effect of the Dormex treatments on the parameters evaluated.

\begin{tabular}{|c|c|c|c|c|}
\hline \multirow[t]{2}{*}{ Evaluated parameters } & \multicolumn{3}{|c|}{ Dormex concentration } & \multirow[t]{2}{*}{$\begin{array}{l}\text { Significance } \\
\text { level }\end{array}$} \\
\hline & $0 \%$ & $4 \%$ & $6 \%$ & \\
\hline $\mathrm{N}^{\mathrm{r}}$. of breaking buds & $226 \mathrm{a}$ & $260 \mathrm{~b}$ & $267 \mathrm{~b}$ & *** \\
\hline $\mathrm{N}^{\mathrm{r}}$. of vegetative buds & 87 & 69 & 69 & n.s. \\
\hline $\mathrm{N}^{\mathrm{r}}$. of fertile buds & 139 a & $191 \mathrm{~b}$ & $198 \mathrm{~b}$ & *** \\
\hline $\mathrm{N}^{\mathrm{r}}$. of flowers & $424 \mathrm{a}$ & $648 \mathrm{~b}$ & $671 \mathrm{~b}$ & $* * *$ \\
\hline I. A. $(\%)$ & 38 & 42 & 42 & n.s. \\
\hline I. F. & $2.9 \mathrm{a}$ & $3.5 \mathrm{~b}$ & $3.4 \mathrm{~b}$ & $* *$ \\
\hline F. R. & $0.7 \mathrm{a}$ & $1.0 \mathrm{~b}$ & $1.0 \mathrm{~b}$ & *** $*$ \\
\hline Marketable production $(\mathrm{kg})$ & $33.4 \mathrm{a}$ & $47.3 \mathrm{~b}$ & $45.8 \mathrm{~b}$ & **** \\
\hline Fruit dry weight (\%) & 14.5 & 14.4 & 14.2 & n.s. \\
\hline $\mathrm{SSC}\left({ }^{\circ} \mathrm{Brix}\right)$ & 7.4 & 7.6 & 7.4 & n.s. \\
\hline Titrable acidity ( $\mathrm{g} \mathrm{L}^{-1}$ citric acid) & $13.7 \mathrm{a}$ & $13.9 \mathrm{ab}$ & $14.2 \mathrm{~b}$ & $*$ \\
\hline Firmness $(\mathrm{N})$ & 62.8 & 63.6 & 62.8 & n.s. \\
\hline
\end{tabular}

\section{Figures}

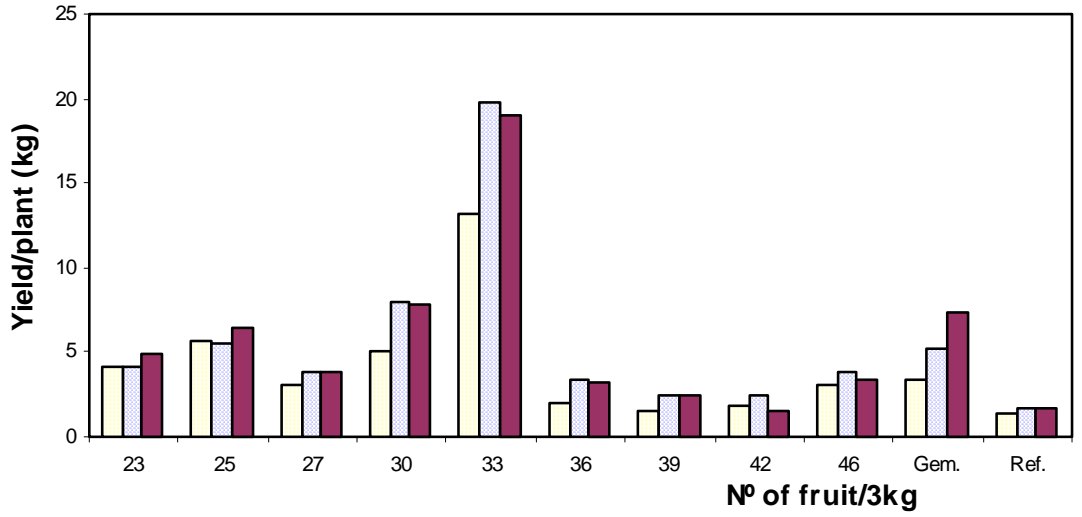

Fig. 1. Kiwifruit separation by categories for the different Dormex treatments.

Gem. = "Fan"-shaped fruit.

Ref. $=$ Other non marketable fruit. 